\title{
Export Barriers and Stimuli in the Russian Federation
}

\author{
Mikalai Dudko
}

\begin{tabular}{|c|c|}
\hline \multicolumn{2}{|c|}{ ABSTRACT } \\
\hline \multicolumn{2}{|c|}{$\begin{array}{l}\text { Objective: The purpose of this article is to identify and analyse existing export barriers } \\
\text { and stimuli in the Russian Federation. }\end{array}$} \\
\hline \multicolumn{2}{|c|}{$\begin{array}{l}\text { Research Design \& Methods: The gravity model is used to identify and assess impact } \\
\text { of informal export barriers and stimuli. Qualitative approach and statistical analysis is } \\
\text { used to identify and assess the impact of formal barriers and stimuli. }\end{array}$} \\
\hline \multicolumn{2}{|c|}{$\begin{array}{l}\text { Findings: Russian export value depends on several informal conditions, such as } \\
\text { distance between trading countries, economic size of a partner country and it } \\
\text { historical heritage. Moreover, there is a wide range of instruments (both internationa } \\
\text { trade and domestic policies) which are used or can be used in the Russian Federation } \\
\text { to influence export performance of particular types of goods. }\end{array}$} \\
\hline \multicolumn{2}{|c|}{$\begin{array}{l}\text { Implications \& Recommendations: Present combination of instruments used suggests } \\
\text { that Russia attempts to restructure its export - to reduce the share of energy } \\
\text { resources and raw materials and increase the one of industrial goods. }\end{array}$} \\
\hline \multicolumn{2}{|c|}{$\begin{array}{l}\text { Contribution \& Value Added: Understanding of current export policies in the Russian } \\
\text { Federation may be useful for short and medium term forecast of Russian economy } \\
\text { development. }\end{array}$} \\
\hline Article type: & research paper \\
\hline Keywords: & tariff; export quot \\
\hline & \\
\hline
\end{tabular}

\section{Suggested citation:}

Dudko, M. (2013). Export Barriers and Stimuli in the Russian Federation. Entrepreneurial Business and Economics Review, 1(3), 35-56. 


\section{INTRODUCTION}

The Russian Federation, being one of the world largest and most influential economic players with the 7th place in GDP PPP rating according to the CIA open database, recently has become even more intriguing object of economic research after entering the World Trade Organization. While specialists in WTO are working hard to compile the Trade Policy Review for Russia (which might be much more difficult to do than for Vietnam or Costa Rica), others try to provide their own basic analysis of Russian trade - specifically of export, concentrating on barriers and stimuli.

The main aim of the article is to analyse current export-affecting tools which are used in Russia. According to the main purpose the following research tasks were established:

- To build a gravity model of Russian export to identify and analyse informal barriers.

- To identify and assess influence of formal barriers on Russian export.

- To identify and assess influence of formal stimuli on Russian export.

\section{LITERATURE REVIEW}

Among works dedicated to the topic of export barriers one should mention Anderson and Wincoop (2004) who concentrated on describing trade costs impact on international trade using gravity model. As trade costs authors name transportation cost, tariff and non-tariff barriers, legal obstacles and others. Kneller and Pisu (2011) analyse export barriers for British small and medium enterprises, which tend to export or already have some international trade experience.

Usage of gravity models has recently become a very widespread method for empirical studies of international trade in emerging markets. Especially, some works should be mentioned here: Suvankulov and Guc (2012) - gravity model of trade (panel data approach) for the Central Asia; Felipe and Kumar (2012) - gravity model of trade (standard approach) for the Central Asia with the LPI index introduced as a dummy variable; and Rahman (2003) - gravity model (panel data approach) applied to the Bangladesh's trade. Iwasaki and Suganuma (2013) and Weckström (2013) should be mentioned as authors of works dedicated to Russian international trade.

\section{MATERIAL AND METHODS}

Taking the main purpose and research tasks into consideration and based on the literature study, the following research hypotheses were assumed:

H1: There is a negative relation between implementation of export barriers and Russian export.

H2: There is a positive relation between implementation of export stimuli and Russian export.

H3: The actual combination of barriers and stimuli has been oriented on restructuring of Russian export. 
With respect to defined operational aims and hypotheses the following research approaches and methods were used:

a) Quantitative: statistical analysis, specifically regression analysis (gravity model - cross-sectional approach) and trend analysis, performance data.

b) Qualitative: document data.

The reason why the aforesaid methods are chosen hides in the nature of export barriers and stimuli - while the influence of some trade policies' tools (e.g. tariffs) is relatively easy to trace, the impact of others (e.g. quotas) is more profound and in the current paper only a set of tools and the practice of their implementation can be described according to the documents available.

\section{RESULTS AND DISCUSSION}

\section{Export Overview}

Basic information about the Russian economy condition are provided in Figure 1. In 2012 Russian GDP (constant 2012 prices, fixed 2012 exchange rate) reached 2 trillion USD thereby exceeding the pre-crisis level. Concerning export, one can see that starting from 1998 its value was significantly higher than the import value.

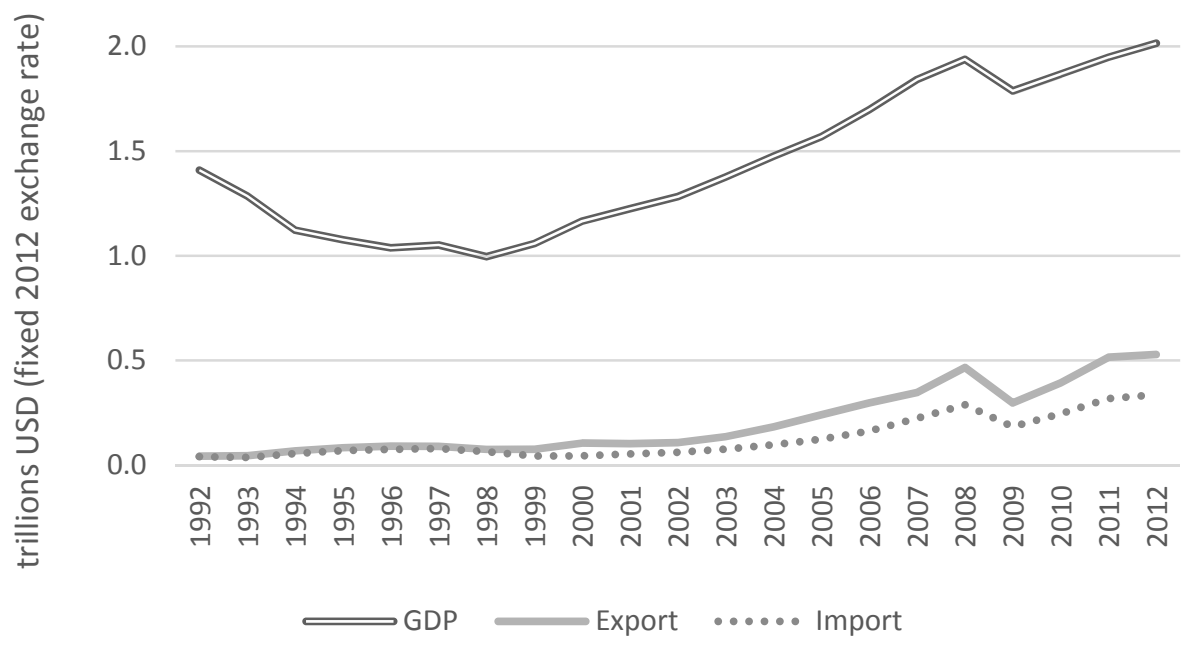

Figure 1. Russian GDP (constant 2012 prices), export and import,1992-2012

Source: own studies based on statistics database of Passport GMID.

For more detailed export analysis the monthly data 2000-2012 were used (Figure 2a). The dotted line indicates linear trend $E X=3009.075+265.281 * t$. The application of natural logarithm of export value with the following examination of detrended data - the autocorrelation analysis - suggests that there is a repeatable annual pattern of Russian export (see Figure $2 b$ ). 


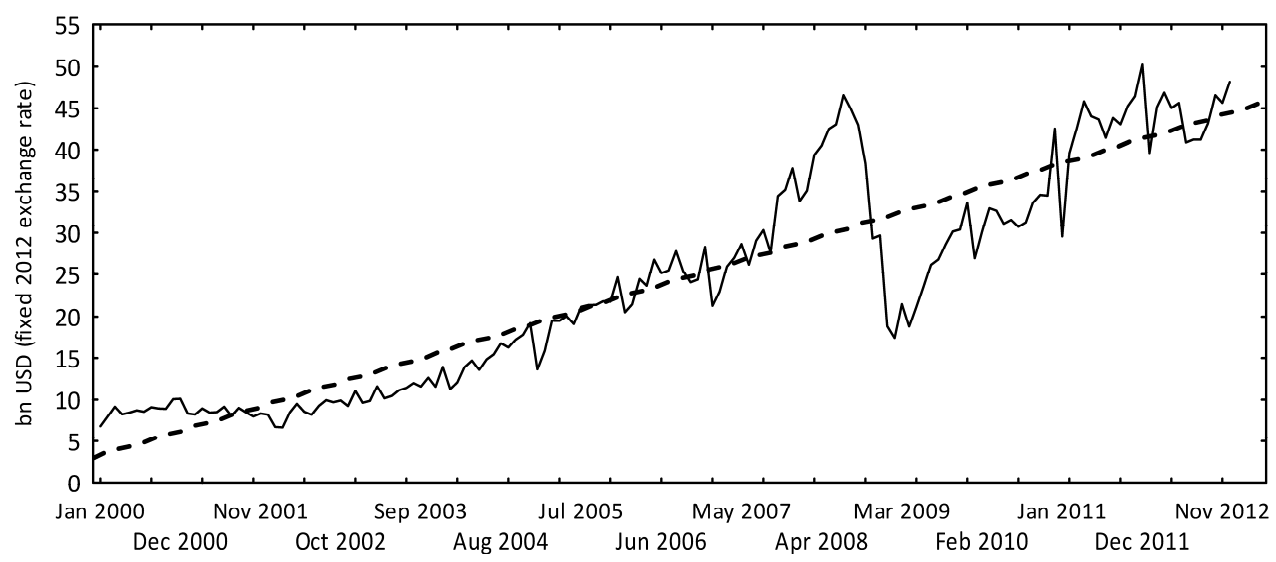

Figure 2a. Export performance, January 2000-December 2012

Source: own studies on the basis of based on Passport - statistics database.

Autocorrelation Function

(Standard errors are white-noise estimates)

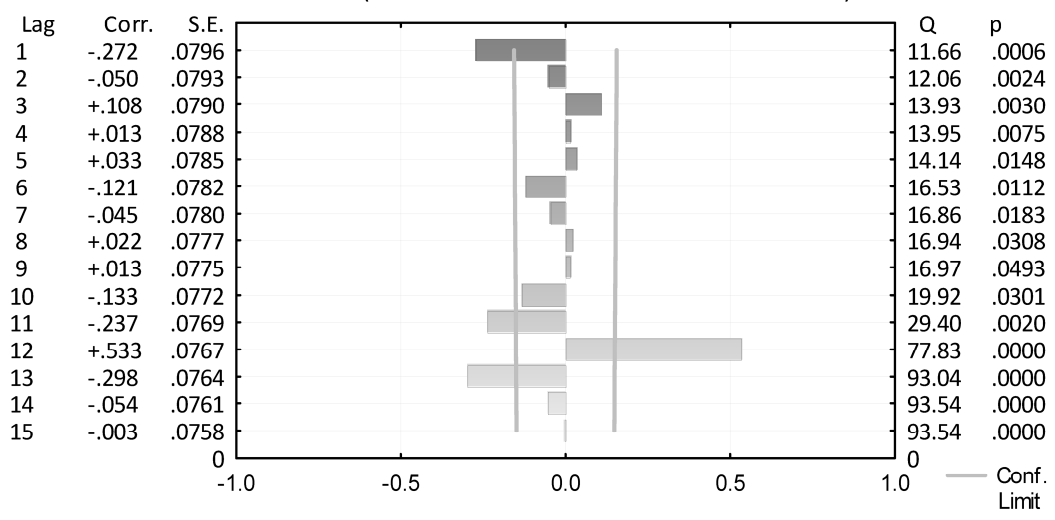

Figure 2b. Export performance - Autocorrelation analysis results

Source: own studies on the basis of based on Passport - statistics database.

Concerning export's structure by country, it must be admitted that distribution of the largest shares has not changed a lot in the past three years - the Netherlands, Italy and Germany are traditionally the largest export partners (Figure 3). However, the Herfindahl-Hirschman Index calculated for 0.5 indicates a low market concentration. A significant share of export also goes to Commonwealth of Independent States (hereafter referred to as CIS). Additionally, it is necessary to mention an increased goods flow to China - this tendency may be continued in the light of the latest progress in gas contract negotiations.

Export structure by type of good also has not changed much: circa $70 \%$ is energy resources, 4-5\% - iron, steel and their products and 3-4\% constitutes for an unknown SS category in the Harmonized System (HS) of tariff nomenclature which is presumably introduced for some special goods withdrawn from usual circulation. Since in the Russian 
Customs Statistics of Foreign Trade that code is described as a "secret code" the assumption above seems to be the most probable explanation.

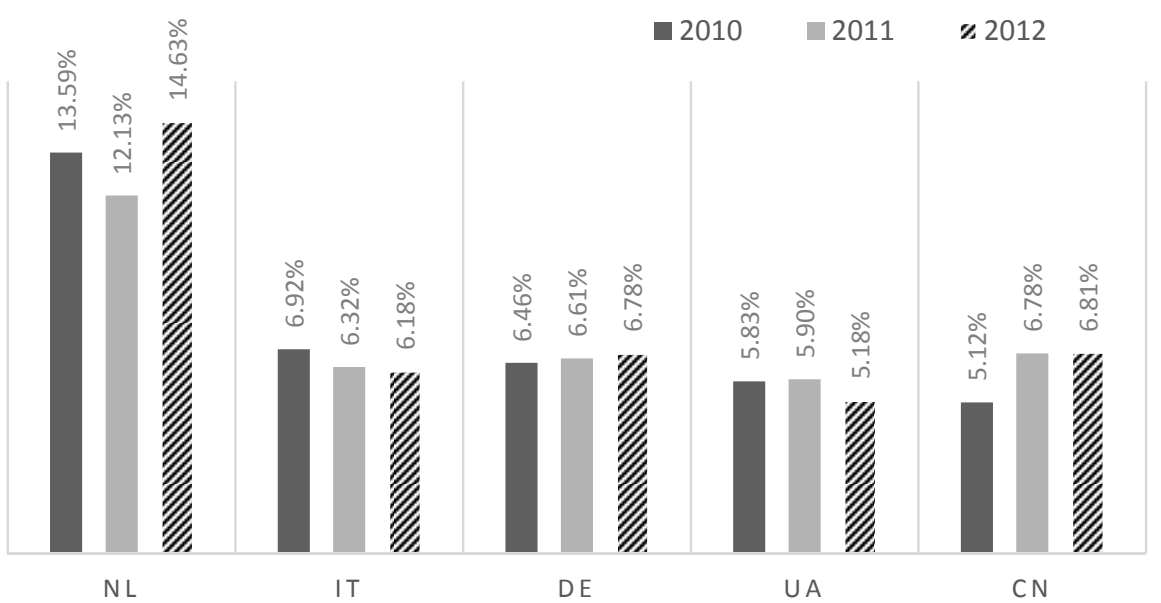

Figure 3. Export structure by country - main trade partners

Source: own studies based on data from Customs statistics of foreign trade.

\section{Gravity Model of Russian Export: Informal Barriers/Stimuli}

To provide more detailed analysis of Russian export trends and to identify existing informal barriers it was decided to build a simple gravity model of Russian export. Scientific works of Rahman (2003) and Felipe and Kumar (2012) were used to create this model. Due to the mathematical nature of the research any possible barrier with the opposite sign can be also considered as a stimulus and vice versa. The export value from Russia to a country $k$ was chosen as a dependent variable, $X_{R k}$. The set of independent variables was the following: $Y_{k}-$ GDP of country $k$; $y_{R k}$ - difference between GDP per capita in Russia and in a target country; $\mathrm{INF}_{\mathrm{k}}$ - inflation rate in a target country; $\mathrm{DIS} \mathrm{R}_{\mathrm{Rk}}-$ the distance between the capital an importing country and Moscow (because of the fact that the level of development of Russian infrastructure, cities etc. is not homogeneous it would be unwise to use distance from some state to the border of the largest country in the world), retrieved from DistanceFromTo website; $\mathrm{HER}_{\mathrm{k}}-1$ if the importing country was formerly one of the Soviet Union Republics, 0 - otherwise, this dummy variable integrates all such features as sharing common language, resembling culture and legislation; $\mathrm{WTO}_{k}$ - being a member of the WTO, 1 if true, 0 if false; $\mathrm{LPI}_{k}-$ (Logistics Performance Index) - this variable was chosen to describe the ease of movement of goods per se; the Index defined by the World Bank is based on survey of international trade operators. $\mathrm{BOR}_{\mathrm{k}}$ - sharing the common border with country $k, 1$ if true, 0 if false.

Such dummy variable as participation in regional trade organizations (e.g. CISFTA) was not included, because all the countries, which had been in the USSR, participate in regional trade agreements. 
The initial model had the following form:

$$
\begin{aligned}
\ln X_{R k}= & \beta_{0}+\beta_{1} \ln Y_{k}+\beta_{2} \ln y_{R k}+\beta_{3} I N F_{k}+\beta_{4} D I S_{R k}+ \\
& +\beta_{5} H_{E} R_{k}+\beta_{6} W T O_{k}+\beta_{7} L P I_{k}+\beta_{8} B O R_{k}+\varepsilon_{k}
\end{aligned}
$$

The sample included 88 countries with which Russia was trading in 2012. Initial hypotheses were that:

1. variables $\mathrm{Y}_{k}, \mathrm{HER} \mathrm{R}_{\mathrm{k}}, \mathrm{LPI}_{\mathrm{k}}$, and $\mathrm{BOR}_{\mathrm{k}}$ would have a positive effect on export,

2. variables $I N F_{k}$ and $D I S_{R k}$, were expected to have negative effect on export,

3. variable $\mathrm{y}_{\mathrm{Rk}}$ could be either positive or negative.

\begin{tabular}{|c|c|c|c|c|c|c|}
\hline \multicolumn{7}{|c|}{$\begin{array}{l}\text { Regression Summary for Dependent Variable: InXRk (Gravity) } \\
R=.80813335 R^{2}=.65307950 \text { Adjusted } R^{2}=.61794831 \\
F(8,79)=18.590 p<.00000 \text { Std.Error of estimate: } 1.0456\end{array}$} \\
\hline $\begin{array}{c}\text { Variables } \\
(\mathrm{N}=88)\end{array}$ & $\mathbf{b}^{*}$ & Std. Err. of $b^{*}$ & b & Strd. Err. of b & $\mathrm{T}(78)$ & $p$-value \\
\hline Intercept & - & - & -2.0870 & 1.2123 & -1.7216 & 0.0891 \\
\hline $\ln Y_{k}$ & 0.4807 & 0.0951 & 0.4814 & 0.0952 & 5.0572 & 0.0000 \\
\hline $\mathrm{Y}_{\mathrm{Rk}}$ & 0.3029 & 0.1062 & 0.0000 & 0.0000 & 2.8530 & 0.0055 \\
\hline $\mathrm{INF}_{\mathrm{k}}$ & 0.0412 & 0.0809 & 0.0078 & 0.0152 & 0.5093 & 0.6120 \\
\hline $\mathrm{DIS}_{\mathrm{Rk}}$ & -0.4382 & 0.0758 & -0.0002 & 0.0000 & -5.7809 & 0.0000 \\
\hline $\mathrm{HER}_{\mathrm{k}}$ & 0.2720 & 0.0884 & 1.3329 & 0.4333 & 3.0761 & 0.0029 \\
\hline $\mathrm{WTO}_{\mathrm{k}}$ & 0.0160 & 0.0850 & 0.0696 & 0.3705 & 0.1878 & 0.8515 \\
\hline $\mathrm{LPI}_{\mathrm{k}}$ & 0.4658 & 0.1329 & 1.3856 & 0.3955 & 3.5038 & 0.0008 \\
\hline $\mathrm{BOR}_{\mathrm{k}}$ & 0.1782 & 0.0809 & 0.8734 & 0.3964 & 2.2035 & 0.0305 \\
\hline
\end{tabular}

Table 1. Regression results for dependent variable $\ln X_{\mathrm{Rk}}$

Source: own study based on the Statistica software.

Results of multiple regression analysis are presented it the table 1 . Significant variable are in bold. Accordingly, variables $\mathrm{INF}_{\mathrm{k}}$ and $\mathrm{WTO}_{\mathrm{k}}$ were found insignificant. Their consecutive elimination did not change significance of other variables. However, the multicollinearity testing showed that there was a strong correlation between $\mathrm{LPI}_{\mathrm{k}}$ and $\ln \mathrm{Y}_{\mathrm{k}}$ and $\mathrm{Y}_{\mathrm{Rk}}$ - thus variable $\mathrm{LPI}_{\mathrm{k}}$ was also eliminated from the model. This step caused a subsequent elimination of $\mathrm{y}_{\mathrm{Rk}}$ and $\mathrm{BOR}_{\mathrm{k}}$, both marked as insignificant. Hence, in the end only three independent variables were found to have significant influence on Russian export (see Table 2).

The final model had the following form:

$$
\ln X_{R k}=\beta_{0}+\beta_{1} \ln Y_{k}+\beta_{4} D I S_{R k}+\beta_{5} H E R_{k}+\varepsilon_{k}
$$

The results received may be interpreted in the following way:

- There is a strong positive relation between Russian export value and the size of economy of partner country - Russian export to country $k$ will augment by $0.651 \%$ if GDP of trade partner increases by $1 \%$. It seems logical that Russia tends to trade with 
larger countries or it may happen that larger countries try to buy more goods from Russia.

- Distance has a negative impact on export - an increase in distance between trading countries by $1 \%$ leads to $0.0002 \%$ drop in export. This dependence seems to reflect the influence of transportation costs.

- Sharing the common Soviet heritage was also found to be significant - export from Russia to post-soviet countries is more than four times higher [exp(1.621652)$1=4.06]$. Presumably, the economic relations that were established during the Soviet era between countries proved to be stronger than political ones.

- The WTO membership of partner country, however, does not influence Russian export - i.e. does not facilitates the trade as it was expected. The possible explanation is that with those few countries which are not in the WTO Russia have bilateral trade agreements and, besides, Russia is an economic player serious enough not to pay much attention to the fact that its trading partner is not in the WTO (e.g. Belarus).

- Inflation rate does not influence the bilateral trade flow.

- The difference between GDP per capita was not defined as significant as well, suggesting that personal welfare level in the country does not influence the trade.

- Common border also does not play any significant role. The possible reasons are firstly, the fact that Russia is large but not homogenously developed country and, secondly, participation in international trade agreements with neighbour countries which nullifies effect of having/not having common border.

Table 2. Final regression results for dependent variable $\ln X_{\mathrm{Rk}}$

\begin{tabular}{|c|c|c|c|c|c|c|}
\hline \multicolumn{7}{|c|}{$\begin{array}{l}\text { Regression Summary for Dependent Variable: InXRk (Gravity) } \\
R=.75396427 R^{2}=.56846212 \text { Adjusted } R 2=.55305005 \\
F(3,84)=36.884 p<.00000 \text { Std. Error of estimate: } 1.1309\end{array}$} \\
\hline $\begin{array}{c}\text { Variables } \\
(\mathrm{N}=\mathbf{8 8})\end{array}$ & $\mathbf{b}^{*}$ & Strd. Err. of b* & b & Strd. Err. of b & $T(78)$ & $p$-value \\
\hline $\ln _{y k}$ & - & - & 0.3158 & 0.9913 & 0.3185 & 0.7509 \\
\hline $\mathrm{DIS}_{\mathrm{Rk}}$ & 0.6505 & 0.0790 & 0.6513 & 0.0791 & 8.2382 & 0.0000 \\
\hline $\mathrm{HER}_{\mathrm{k}}$ & -0.4816 & 0.0763 & -0.0002 & 0.0000 & -6.3089 & 0.0000 \\
\hline
\end{tabular}

Source: own study based on the Statistica software.

In summary, one can conclude that the size of the economy and sharing common legal, cultural and language heritage can be stimuli for Russian export, while the distance between trading countries is an obstacle for the goods flow. Thus, Russia tends to develop the export to near abroad countries or to ex-partners from USSR. Adjusted $\mathrm{R}^{2}=$ 0.55 , which is a strong figure for this type of models, means that the model explains $55 \%$ of original variability. However, it is possible that usage of a panel data approach may result in more reliable model and make some of aforesaid variables significant, as far as variable fluctuations over time will be taken into consideration. 


\section{Formal Barriers - Tariffs}

The general rule is that there are no export taxes within the Eurasian Customs Union (except oil and its products). Export tariffs to the CIS countries are also reduced or cancelled (Agreement on the Creation of a Free-Trade Area of 2011). In case the good which is an object of export restriction in other member of Customs Union and originated from this state is exported from the Russian Federation, the appropriate tax will be levied (Agreement on the Common Customs-Tariff Regulation with Respect to Third Countries of 2008). It must also be mentioned that any tariff rate can be a subject of negotiations between countries - according to some bilateral agreements export tariffs can be reduced. The example of such exception was export tariff for gas to the Ukraine (Decision of the Government of the Russian Federation No. 291 of 2010).

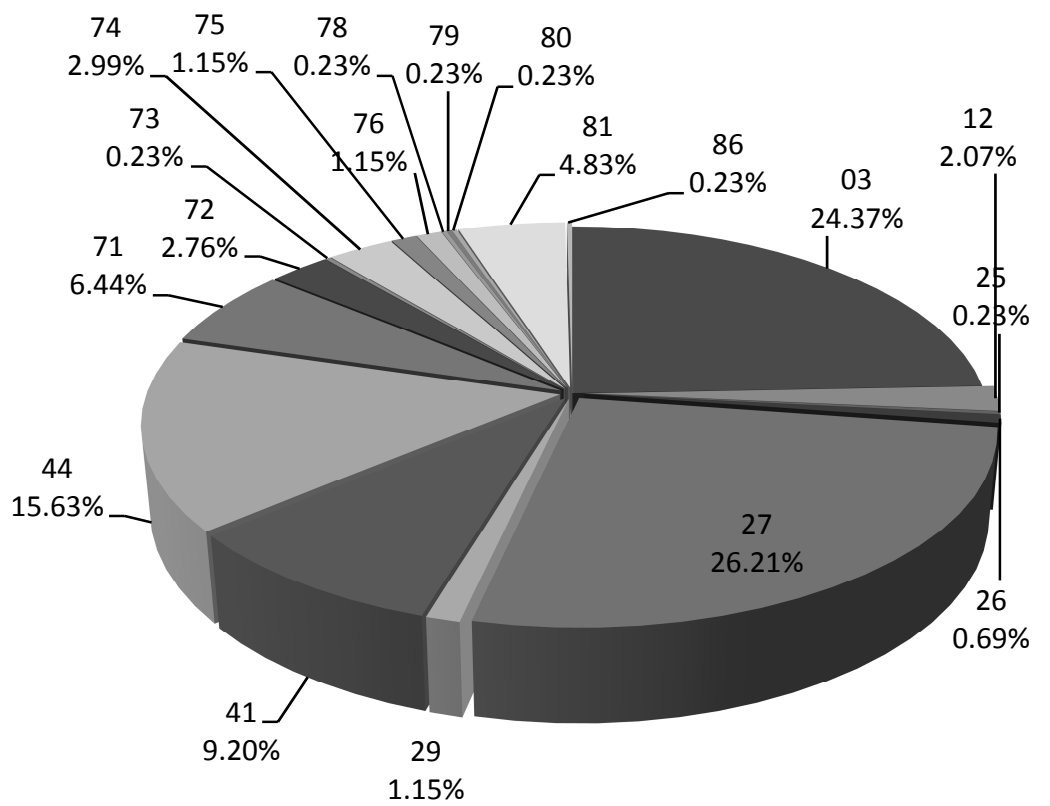

Figure 4. Tariff structure by type of good (2 digit HS codes) (30.08.2013)

Source: own studies based on Decision of the Government of the Russian Federation No. 754 of 2013.

In the Russian Federation export tax is imposed on around 435 10-digit goods groups (temporary tariffs were counted, several different tariffs within one 10-digit group was counted separately) (see Figure 4) against 426 in May 2012 - several months before the entry to the WTO; $5 \%$ of implemented taxes are specific, $46 \%$ are ad-valorem and $49 \%$ - combined.

The comparison with the previous period before the entry of Russia to the WTO reveals that share of implementation of specific tariff decreased while combined tariff became more frequently used.

For a more detailed analysis of export tariffs one group of goods was chosen, namely crude oil and some of its products. These goods are part of 27 and 29 HS 2-digit group which together represent $70 \%$ of Russian export; $27.36 \%$ of implemented export 
taxes fall at these two groups. These export tariffs are controlled more strictly and changed every month. Moreover, the foreign demand on these products is very high, which may suggest that in this case export tariffs will not be able to influence negatively the export. The sample used for the analysis covers monthly data of all tariffs implemented for all dutiable 10-digit goods that fall into category of oil and its products for the period from December 2009 to September 2013. Hence, the sample consists of 46 cases and 99 variables. For the simplicity export taxes 10-digit groups were transformed into average export tax for each 4-digit group.

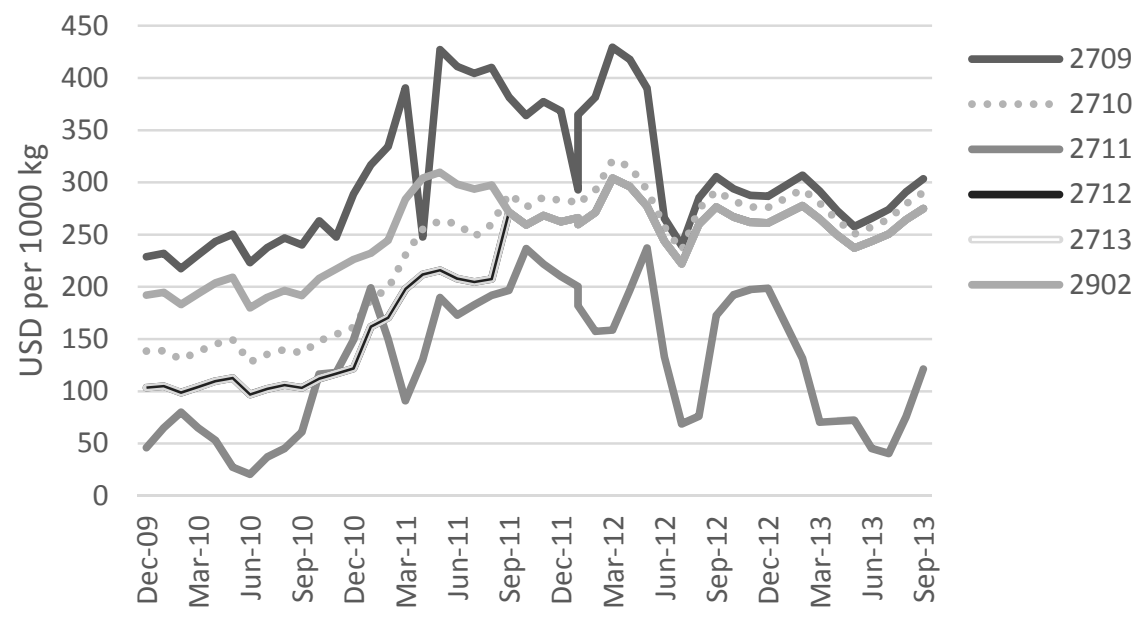

Figure 5. Monthly values of export tax on oil and its product from December 2009 to September 2013

Source: own studies based on Decision of the Government of the Russian Federation No. 695 of 2006.

The convergence can be distinctly seen on the graph (Figure 5). One can see that systematic work on the unification of export tariff rates started in September 2011. The largest simultaneous decrease reflects the period directly preceding the accession to the WTO. The suggestion may be provided that the sharp lowering of export tax for all goods described and especially for crude oil (2709) was too much artificial and demonstrative to meet the WTO requirements. One may suggest that tariffs may not go down but will only grow in the future. However, the export tariff for oil may be interesting for research because it is seems to be not a trade barrier in the classical meaning. In principle, export tariff should reduce export, but for such product as oil this relation may not be valid.

The regression analysis where lagged $(t-1)$ export tariff for oil and its products was chosen as an independent variable and the export value in month $t$ (the tariff is usually introduced at the end of the month and, consequently, might influence export in the following month) was provided with the following assumptions:

- Export tax for 4-digit groups of goods (2709, 2710, and 2711) was an average tax calculated only for all dutiable 10-digit goods that are included in this 4-digit group, not taking into consideration 10-digit goods that are not dutiable. 
- Export value of 4-digit group of goods was a sum of export value of all 10-digit goods, dutiable and not dutiable, within current 4-digit group. As far as dutiable 10-digit products represented either entire 4-digit group or its significant part, such level of specification was assumed to be reliable.

The analysis brought interesting results - the correlation was positive (see Table 3). The conclusion that export tariffs stimulate export seems to be highly implausible. It is, however, possible that the rise in oil products export causes an increase of export tax value. Confirmation of this can be also found in the latest versions of law concerning export tax calculation methodology - the tariff depends directly on international oil price (Decision of the Government of the Russian Federation No. 276 of 2013). Hence, it is possible to affirm that in the Russian Federation export duties for oil and its products do not play the role of export barriers, but have a fiscal function.

Table 3. Regression results for crude oil and its products (4-digit HS groups)

Source: own study based on the Statistica software.

\begin{tabular}{|c|c|c|}
\hline $\begin{array}{c}\text { Dependent variable } \\
\text { - export value }(\mathbf{N}=\mathbf{4 5})\end{array}$ & $\begin{array}{c}\text { Independent variable } \\
- \text { export tariff }\end{array}$ & Significance \\
\hline $\operatorname{In} 2709 E x U S D$ & $\ln 2709 \mathrm{~T} \mathrm{~b}=0.549$ & significant \\
\hline $\ln 2710 \mathrm{ExUSD}$ & $\ln 2710 \mathrm{~T} \mathrm{~b}=0.61$ & significant \\
\hline $\ln 2711 \mathrm{ExUSD}$ & $\ln 2711 \mathrm{~T} \mathrm{~b}=0.361$ & significant \\
\hline
\end{tabular}

Concerning other widely exported goods, the tariffs for them can be implemented because of:

a) Legal reasons - export tariff for ferrous and non-ferrous scrap is imposed on 24 goods from 72, 75, 76, 78, 79, 80 and 81 HS group. Russia, being one of world largest exporters of ferrous and non-ferrous scrap (Karpenko, 2013), implements the tax to reduce the profitability of this activity - making primary purchase price less attractive for the population and, subsequently, preventing the crimes and damages to enterprises and infrastructure.

b) Raising additional capital for certain sector of production - timber, 44 HS group. Moreover, tax for timber export in some sense favours the ecology by reducing volumes because of lower profitability.

\section{Formal Barriers - Non-Tariff Barriers}

In Russia non-tariff export restrictions can be divided into: prohibitions, restrictions of export per se of particular good and quantitative restrictions of export of particular good. It is prohibited to export: certain ozone damaging products; data carriers which contains extremist information or other information that can cause moral damage; several kinds of personal weapon and its parts, ammunition (Resolution of the Collegium of the EurAsEc Economic Commission No. 134 of 2012).

To export restricted goods (by quantity or by nature of good) an exporter needs to have a license from the state or international organization, which controls movement of such kind of goods (Federal Law No. 164-FZ of 2003). A license can be general or valid for one occasion (Agreement on the Rules for Licensing in the Sphere of Foreign Trade in 
Goods of 2009). The general license allows an economic player to export certain quantity of goods during a period of time no longer than one year, while valid for one occasion license is given on the basis of a contract and allows to export once the quantity specified in it.

Certain types of goods originated from Russia are restricted to export: certain ozone damaging substances; dangerous waste products; mineralogy and palaeontology collections and their parts; living wild animals and plants (including endangered species), and some of their products (e.g. caviar); some precious metals and precious stones (including waste products, fragments and raw materials); mineral raw materials; narcotics, psychotropic substances and their precursors; poisonous substances; facilities for secret access to information and cryptographic hardware; historical and cultural values; parts of human body, blood and its components; personal weapon and its parts, ammunition (Resolution of the Collegium of the EurAsEc Economic Commission No. 134 of 2012); and others, which can be defined by Russian government or international agreements. Moreover, the Russian Federation controls movement of goods which are objects of export control - goods that can be directly used as weapons of mass destruction or means of delivery and dual-purpose goods. The majority of aforesaid restrictions come from the world practice of restrictions and prohibitions for defined range of goods; hence the change in flow of denoted goods will be limited and connected rather with some other factors than trade policies.

Quantitative restrictions are in a form of quotas. Distribution of quota on goods is put into practice in a form of equal, non-discriminating auction among economic agents. For all the members of the Customs Union there are the same rules of implementation of quotas to the third countries. The most general of them is the rule of non-discrimination - restrictions must concern only certain types of goods (Trade in Goods on the Common Customs Territory with Respect to Third Countries of 2009), unless the restrains result from some bilateral agreement between Russia and the third country (Agreement on the Common Measures of Non-Tariff Regulation with Respect to Third Countries of 2008). Generally, all the measures connected with quantitative restrictions of export are elaborated in cooperation with all member states of the Customs Union. However, there are also possibilities of unilateral implementation of quotas or prohibitions for a sixmonth period. The following economic reasons can be behind unilateral or mutual implementation of export restrictions: prevention of exhaustion of natural resources, fighting deficit of foodstuff or any other goods that are found crucial for the domestic market (Trade in Goods on the Common Customs Territory with Respect to Third Countries of 2009). As far as raw materials play an important role in Russian export structure, one can conclude that any export restriction connected to them can be easily justified by the state.

Quantitative restrictions of export are not implemented officially in Russia in 2013. However, there are voluntary export restrains of some steel products to European Community (Agreement between the Russian Federation and the European Community on Trade in Certain Steel Products of 2005) and to the USA (Agreement Suspending the Antidumping Investigation on Certain Hot-Rolled Flat-Rolled Carbon-Quality Steel Products from the Russian Federation of 1999). This and the fact that steel products (72group) are included into the list of crucial products may make one think that even though 
Russia participates in the agreement that unifies and restricts implementation of export quotas, it has a relative freedom for providing its own export policy. Quantitative restrictions can be implemented in Russia at any time if the state finds it indispensable to do so.

There can be also established a monopoly on export of certain goods (Federal Law No. 164-FZ of 2003). In that case exceptional license is given to an economic agent (Agreement on the Rules for Licensing in the Sphere of Foreign Trade in Goods of 2009). At present, there is a monopoly of trade for two types of goods - petroleum gases and other gaseous hydrocarbons; liquefied/in gaseous state natural gas - which is realized by JSC Gazprom (Protocol Resolution of Economic Council of the CIS on the Review of Trade Policy of the Russian Federation of 2012).

For several goods the tariff quota is established with the obligation of having license - Spruce fir "Picea abies Karst" and noble fir "Abies alba Mill" and Archangel fir "Pinus sylvestris L." (Decision of the Government of the Russian Federation No. 779 of 2012).

Another special type of restrictions that should be mentioned is "setting up the surveillance". According to the law the surveillance is used to scrutinize flows of particular goods for which other method of recording is inapplicable. However, in reality it means that economic parties must have not a license, but a permission to export a certain quantity of these particular goods (Agreement of the Procedure for the Introduction and Application of Measures Dealing with Foreign Trade in Goods on the Common Customs Territory with Respect to Third Countries of 2009). Even though the permission must be given to any economic agent that applies for it (Agreement on the Rules for Licensing in the Sphere of Foreign Trade in Goods of 2009) the additional paperwork may complicate the export.

It is important to admit, that for some types of goods there are no direct restrictions of export, but at the same time there are some hidden restriction. The example is licensing for production and storage of alcohol (Federal Law No. 171-FZ). These requirements indirectly impede exports as far as export usually implies earlier production and storage. The same situation is with ferrous and non-ferrous scrap - there are no direct restrictions for export, but at the same time storage, recycling and sale of these goods requires a license (Decision of the Government of the Russian Federation No. 1287 of 2012).

Another hidden barrier for export can be an obligation of export of certain goods through the particular custom offices. This may augment the price - distance and waiting time increases transportation costs. Before 2004 Russia was quite actively using this tool for ferrous and non-ferrous scraps (Order of the State Customs Committee of the Russian Federation No. 1219 of 2000) and several sorts of timber (Order of the State Customs Committee of the Russian Federation No. 184 of 2000). At present this kind of barrier is not used, though still there is a legal option of its implementation for any type of goods (Federal Law No. 311-FZ of 2010).

Concerning domestic policies that may negatively influence export one should mention domestic tax for mining operations - specifically applied to fossil fuels (oil, gas, peat etc.), ores and some other raw materials (Tax Code of the Russian Federation of 2000). 


\section{Stimuli - Guaranties and Crediting from the Eximbank}

Since 2003 for facilitation of export to emerging markets the Russian Federation has been providing measures to lower risks for involved economic agents who export industrial goods. The term "industrial goods" includes goods from more than three hundred 4-digit groups of goods (Order of the Government of the Russian Federation No. 1222-r of 2004). For that purpose the special bank, Eximbank of Russia, was created as an agent bank. The bank targets goals concerning export stimulation such as issuing of government guaranties and crediting. The guaranties include:

1. Government guarantee to Russian exporters to secure payment obligations.

2. Government guarantee to banks (foreign or national) to secure credit payments obligations resulting from banks' export crediting activities.

3. Government guarantee to Eximbank of Russia to secure debts and guarantees issued by the bank; to secure its obligations of transactions connected with export supporting activity; to secure its obligations of bank guaranties towards Russian exporters (Order of the Government of the Russian Federation No. 1493-r of 2003).

Table 4. Government guarantees: list of countries and limits

\begin{tabular}{|l|r|r|}
\hline \multicolumn{1}{|c|}{ Country } & $\begin{array}{c}\text { \% of contract } \\
\text { price }\end{array}$ & $\begin{array}{c}\text { Millions of } \\
\text { USD }\end{array}$ \\
\hline Algeria, Belarus, Brazil, Vietnam, Egypt, Indonesia, Peru & $95 \%$ & 1000 \\
\hline Angola, Venezuela, Jordan, Columbia, Turkey, Philippines & $90 \%$ & 500 \\
\hline $\begin{array}{l}\text { Argentina, Iran, Yemen, Macedonia, Namibia, Morocco, Serbia, Tunisia, } \\
\text { Nigeria }\end{array}$ & $85 \%$ \\
\hline $\begin{array}{l}\text { Albania, Bosnia and Herzegovina, Gabon, Guatemala, Kenya, Costa Rica, } \\
\text { Maldives, Panama, Paraguay, El Salvador }\end{array}$ & $85 \%$ \\
\hline $\begin{array}{l}\text { Azerbaijan, Armenia, Bangladesh, Belize, Georgia, Cuba, Tajikistan, } \\
\text { Lebanon }\end{array}$ & 100 \\
\hline Kirghizia, Moldova, Turkmenistan, Uzbekistan, Ukraine & $85 \%$ & 50 \\
\hline
\end{tabular}

Source: prepared by the author on the basis of Order of the Government of the Russian Federation No. 566-r of April 25, 2008 and Order of the Government of the Russian Federation No. 1493-r.

The volume of the Government support is defined in the annual Federal Budget. Guarantees without individual limits can be given if goods are exported to any country with credit rating higher than BBB. Additionally, there is in a list of countries with lower credit rating for which guaranties are also provided (see Table 4). The limit of guarantee amount depends on which group the country belongs to.

It is necessary to admit that adding to the aforesaid gravity model a possibility of government guaranties as a dummy variable shows no significant correlation, suggesting the guaranties have no impact on total export. However, it can be explained by the fact that that share of the goods to which this instrument is applied in total export is very small.

Credits are also widely used to augment export of industrial goods. Credits can be granted for the period from 5 to 20 years (Eximbank Annual Reports) and may cover 85\% of the contract price ( $100 \%$ in exceptional cases - priority export projects) (Order of the Government of the Russian Federation No. 1493-r of 2003). The credits are financed 
from the Federal budget (completely or partially) and granted to foreign importers, foreign banks or governments of foreign states (Order of the Government of the Russian Federation No. 1493-r of 2003).

For Russian exporters (especially of industrial goods, but not necessarily) special pre-export credits are also provided.

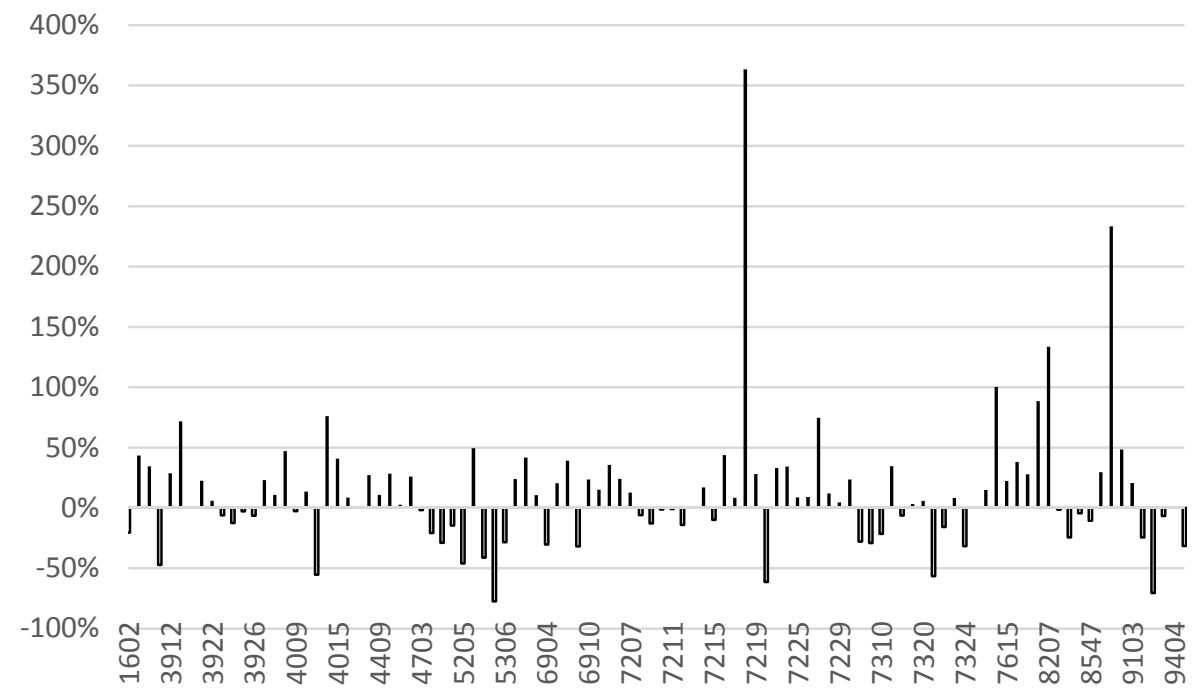

Figure 6. Changes of export value of goods for which export guaranties and crediting were implemented

Source: own studies based on Customs statistics of foreign trade and Order of the Ministry of Industry and Trade of the Russian Federation No. 518 of 2012.

To check if the guarantees and crediting stimulate export it was decided to compare the export performance of goods for which these stimuli were implemented in different periods. The model had the following assumptions:

1. The sample included goods for which only guaranties and export crediting are applied. It means that industrial goods with high level of processing were excluded from the list of industrial goods. That must allow assessing the pure influence of this stimulus on the export performance.

2. The quality of export data did not allow to use deeper specification than 4-digit goods group. Thus the final sample represents export only for 102 4-digit groups.

3. Timeframe is 3 years $-2010-2012$. The difference will be shown between the first and the third years of observation.

Figure 6 shows that for the large part of industrial goods which were stimulated by government guaranties export increased in the last two years. At the same time export of some goods supported in this way decreased. Comparing total performance it was found that in observed period export of the target groups of goods increased by $16 \%$. However, the share of export of the aforesaid groups of goods in the total export 
decreased from $7.56 \%$ to $6.68 \%$. The latter implies that probably in the observed period such stimulus as government guaranties was not as efficient as it should be.

\section{Stimuli - Export Subsidies}

Concerning export subsidies it must be admitted that they are realized in the form of repayment of interest on export credit which was taken from any Russian institutional lender to finance export of Russian industrial high-value-added goods. This group of goods is more specified - it intersects with the group of industrial goods for the most part (Order of the Ministry of Industry and Trade of the Russian Federation No. 518 of 2012) and corresponds to goods which production is more advanced technologically and economically. The share of these goods in total Russian export is insignificant - only $5 \%$ in 2011 (Vnesheconombank Annual Report-2011). The subsidies can be given to: national exporters - winners of tendering, foreign governments which import Russian production, foreign companies which import Russian production (Protocol Resolution of Economic Council of CIS on the Review of Trade Policy of the Russian Federation of 2012; Order of the Government of the Russian Federation No. 1493-r of 2003).

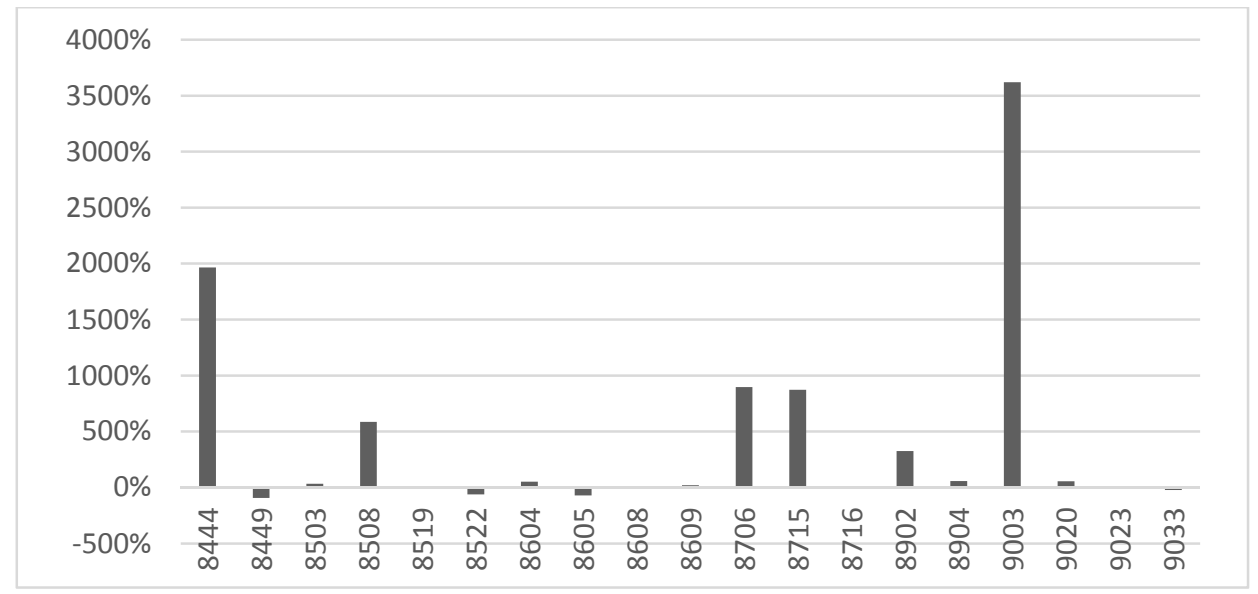

Figure 7. Change in value of export of goods for which export subsidies were implemented Source: own studies based on Customs statistics of foreign trade; Order of the Ministry of Industry and Trade of the Russian Federation No. 518 of 2012.

To assess the effectiveness of this particular kind of stimuli it was decided to compare export of some industrial high-value added goods in different periods. The sample includes 16 4-digit goods groups for which only subsidies where implemented in 2011 and 2012 (see Figure 7).

One can see the strong export performance for which the subsidies were implemented. Total export of industrial high-value-added goods (included the aforesaid outlier) increased by $52.46 \%$ - from 567.5 million USD in 2010 to 865.2 million USD in 2012. Relatively to the total export their share also augmented $-0.14 \%$ in 2010 against $0.16 \%$ in 2012 . One can conclude that export subsidies effectively stimulate export. 


\section{Customs Payment by Instalments and Crediting}

In the Russian Federation there is also some kind of stimuli that can be provided only if a barrier is implemented - it is crediting or giving possibility of payment by instalments of sums of export duty that economic agents are obliged to pay to customs office (Customs Code of the Customs Union, Appendix to the Treaty on the Customs Code of the Customs Union Adopted by Resolution of the Interstate Council of the Eurasia Economic Community No. 17 of 2009). In this case the interest rate which has to be paid (Federal Law No. 311-FZ of 2010) is equal to the refinancing interest rate of the Central Bank of the Russian Federation. That latter fact implies that the interest rate will be lower than any other proposed by commercial banks. The period of time for the aforesaid measures is from one to six months. However, the only technical chance for exporters to receive this credit or possibility to pay in instalments is to have a delay in government financing due.

Hence, the current stimuli can be assumed as a supplementary one in the irrational situation when tariffs and subsidies are implemented. It must be admitted that such a situation exists at the present time - for the goods from 8607191001 HS group combined export tax is levied and, at the same time $8607 \mathrm{HS}$ group is included in the list of industrial high-added value group.

\section{Domestic Subsidies}

Generally, subsidies can be used in Russia including cases of stimulation of production of goods (Budgetary Code of the Russian Federation No. 145-FZ of 1998). The implementation of domestic subsiding which can influence export depends on Russian international agreements.

Concerning the Customs Union Russia has no right to implement the domestic subsidies for industrial goods which will influence export to other member state if such subsidizing is the main condition for the occurrence of export of the goods. In other cases the subsidies can be implemented (Agreement on the Single Rule of Industrial Subsiding of 2012). The term "industrial goods" does not include the same goods as industrial goods which were mentioned before while analysing export subsidies - it is much broader - 25-97 HS group with few exceptions. Hence, basically the subsidies must not allow helping exporting enterprises to reach the breakeven point. The WTO does not prohibit domestic production subsidies, but at the same time insists that they may have a negative impact on the trade flow between countries and condition the introduction of countervailing measures by the trade partners (Agreement on Subsidies and Countervailing Measures). Moreover, there are exceptional rules for subsidizing agricultural products.

As one can see in Russia there is a possibility to use domestic subsidies as an instrument of export stimulation. However, it seems to be very difficult to examine any effect, positive or not, of these subsidies on export performance - their use is not widely announced and, moreover, quite decentralized - these subsidies can be given from the local budget. The best indicator, that country actively uses domestic subsidies will be the existence of antidumping investigation in relation to Russian goods. Generally, there 
were three antidumping investigations against Russia in recent times (Zubtchenko, 2013).

\section{CONCLUSIONS}

Relying on the research provided, it is possible to conclude that Russia actively uses a wide range of instruments to influence its export. This includes not only standard trade policies, usage of which is rather limited right now because of necessity of the WTO obligations fulfilment, but also some domestic policies, which, while not being directed exactly at export, nevertheless indirectly influence the export performance. Moreover, it is possible to assume that the WTO membership does not restrict Russia so much in choosing trade policy instruments - almost anything can be justified using national legislation.

Concerning informal barriers it was established that such informal barriers as distance, not sharing the common Soviet Union heritage and small economic size of the trade partner significantly negatively influence the export value. At the same time the analysis of the influence of such formal barriers as oil export duties on oil export did not show any negative dependence. However, this result probably comes from the specificity of the good. Concerning quantitative restrictions, their impact on the export is basically defined by their nature. Hidden barriers, in their turn, with high probability negatively influence the export, but this influence is almost untraceable - e.g. one can only suppose how the export would grow if the mining tax was abolished.

The examined sample of goods for which such stimulus as export subsidy was implemented showed that in observed three years period the export of this goods shown a strong growth in absolute value (52.46\%) and in the export share $(0.02 \%)$. In the same period other goods, for which the state offered government guaranties and export crediting showed a moderate growth (16\%) and decrease in total export share $(-0.88 \%)$. That makes doubtful the idea of effectiveness of government guaranties as a stimulus for Russian export. However, it may happen that in a long term this instrument will be more efficient.

The final conclusion is that following the combination of the barriers and stimuli has a macroeconomic aim to restructure Russian export. This conclusion is drawn from the comparative analysis of structure of barriers and stimuli by type of good - barriers are implemented mainly to the raw materials and some other not technology-intensive goods, while export subsidies are used to encourage exporters of industrial and highvalue added industrial goods. One may suppose that Russia seeks to reduce its dependence on petrodollars.

Further research must be dedicated to more advanced trade model which would be possible to use for Russian export development forecast in a short and medium term.

\section{REFERENCES}

Agreement between the Russian Federation and the European Community on Trade in Certain Steel Products of November 3, 2005, signed in Moscow. Retrieved from http://base.consultant.ru/cons/cgi/online.cgi?req=doc;base=INT;n=35903. 
Agreement of the Procedure for the Introduction and Application of Measures Dealing with Foreign Trade in Goods on the Common Customs Territory with Respect to Third Countries of June 9, 2009, signed in Moscow. Retrieved from http://base.consultant.ru/cons/cgi/ online.cgi ?req=doc; base=LAW; $\mathrm{n}=95703$.

Agreement on Subsidies and Countervailing Measures. Retrieved from http://www.wto.org/english/tratop_e/scm_e/scm_e.htm.

Agreement on the Common Customs-Tariff Regulation with Respect to Third Countries of January 25, 2008. Retrieved from http://base.consultant.ru/cons/cgi/online.cgi?req=doc;base=LAW; $\mathrm{n}=93022$.

Agreement on the Common Measures of Non-Tariff Regulation with Respect to Third Countries of January 25, 2008, signed in Moscow. Retrieved from http://base.consultant.ru/cons/cgi/ online.cgi?req=doc; base $=\mathrm{LAW} ; \mathrm{n}=93061$.

Agreement on the Rules for Licensing in the Sphere of Foreign Trade in Goods of June 9, 2009, signed in Moscow (22.06.2011). Retrieved from http://base.consultant.ru/cons/cgi/online .cgi?req=doc;base $=$ LAW; $n=115720$.

Agreement on the Single Rule of Industrial Subsiding of December 9, 2012, signed in Moscow. Retrieved from http://base.consultant.ru/cons/cgi/online.cgi?req=doc;base=LAW; $=113058$.

Agreement Suspending the Antidumping Investigation on Certain Hot-Rolled Flat-Rolled CarbonQuality Steel Products from the Russian Federation of July 12, 1999. Retrieved from http://base.consultant.ru/cons/cgi/online.cgi?req=doc;base=INT; $n=6493$.

Anderson, J.E., \& van Wincoop, E. (2004). 'Trade costs', Journal of Economic Literature, 42(3), 691 751.

Budgetary Code of the Russian Federation No. 145-FZ of July 31, 1998 (07.05.2013). Retrieved from http://base.consultant.ru/cons/cgi/online.cgi?req=doc;base=LAW; $n=146289$.

Customs Code of the Customs Union (Appendix to the Treaty on the Customs Code of the Customs Union Adopted by Resolution of the Interstate Council of the Eurasia Economic Community No. 17 of November 27, 2009 (16.04.2010). Retrieved from http://base.consultant.ru/cons/ cgi/online.cgi?req=doc; base=LAW; $n=100808$.

Customs statistics of foreign trade [in:] Federal Customs Service [online version] http://stat.customs.ru/apex/f?p=101:1:45318581794692.

Decision of the Government of the Russian Federation No. 1287 of December 12, 2012 on the Licensing the Procurement, Storing, Processing of Ferrous and Non-Ferrous Scrap Metals. Retrieved May 2, 2012, from http://base.consultant.ru/cons/cgi/online.cgi?req=doc;base=LAW; $=139116$.

Decision of the Government of the Russian Federation No. 276 of March 29, 2012 on the Computation of the Rates of the Export Customs Duties on Crude Oil and on Certain Categories of Goods Manufactured from Oil and on the Invalidation of Certain Acts of the Government of the Russian Federation. Retrieved May 2, 2012, from http://base.consultant.ru/cons/cgi/

online.cgi?req=doc;base=LAW; $n=144198 ; f l d=134 ; d s t=100009 ;$ rnd $=0.0777619774453342$.

Decision of the Government of the Russian Federation No. 291 of April 30, 2010 on the Rates of Export Customs duties on Natural Gas Supplies from the Territory of the Russian Federation on the Territory of Ukraine. Retrieved from http://base.consultant.ru/cons/cgi/online .cgi?req=doc;base=LAW; $=99921$.

Decision of the Government of the Russian Federation No. 695 of November 16, 2006 on the Approval of the Rates of the Export Customs Duties on Crude Oil and on Certain Categories of Goods Manufactured from Oil and Exported from the Territory of the Russian Federation 
beyond the Borders of the Member States of the Agreements on the Customs Union and on the Invalidation of Certain Acts of the Government of the Russian Federation. Retrieved May 2, 2013, from http://base.consultant.ru/cons/cgi/online.cgi?req=doc;base=LAW; $=144185$.

Decision of the Government of the Russian Federation No. 756 of July 21, 2012 on the Approval of the Rates of Export Customs Duties on Goods Exported from the Territory of the Russian Federation beyond the Borders of the Member States of the Agreements on the Customs Union and on the Invalidation of Certain Acts of the Government of the Russian Federation (22.12.2012). Retrieved from http://base.consultant.ru/cons/cgi/online.cgi?req=doc;base $=\mathrm{LAW} ; \mathrm{n}=139962$.

Decision of the Government of the Russian Federation No. 779 of July 30, 2012 on the Tariff Quotas for Certain Coniferous Lumber Exported from the Territory of the Russian Federation beyond the Borders of the Member States of the Agreements on the Customs Union. Retrieved May 2, 2013, from http://base.consultant.ru/cons/cgi/online.cgi?req=doc;base $=$ LAW; $n=139170$.

Decision of the Government of the Russian Federation No. 877 of December 15, 2007 on the Approval of the List of Goods, Which Are Essentially Important for the Home Market of the Russian Federation, in Respect of Which Temporary Restrictions or Bans on Their Export May Be Introduced in Exceptional Cases. Retrieved May 2, 2013, from http://base.consultant $. r u / c o n s / c g i / o n l i n e . c g i ? r e q=d o c ; b a s e=L A W ; n=126027$.

Decision of the Government of the Russian Federation No. 88 of February 6, 2012 on the Approval of the Rates of the Export Customs Duties on Goods Exported from the Territory of the Russian Federation beyond the Borders of the Member States of the Agreements on the Customs Union and on the Invalidation of Certain Acts of the Government of the Russian Federation (04.05.2012). Retrieved May 2, 2013, from http://base.consultant.ru/cons/cgi/online.cgi?req =doc;base=LAW;n=129393.

DistanceFromTo. Retrieved from http://www.distancefromto.net/.

Eximbank, Annual Reports of the ExImBank. Retrieved May 1, 2013, from http://www.eximbank.ru/reporting/yearly_account/.

Federal Law No. 117-FZ of July 18, 2006 on Gas Export. Retrieved from http://base.consultant .ru/cons/cgi/online.cgi?req=doc;base=LAW; $n=61577$.

Federal Law No. 126-FZ of July 21, 2012 on Ratifying the Protocol on the Accession of the Russian Federation to the Marrakesh Agreement of April 15, 1994 on Establishing the World Trade Organization. Retrieved from http://base.consultant.ru/cons/cgi/online.cgi?req=doc;base $=\mathrm{LAW} ; \mathrm{n}=132905$.

Federal Law No. 164-FZ of December 8, 2003 on the Fundamental Principles of State Regulation of Foreign Trade Activity (28.07.2012). Retrieved from http://base.consultant.ru/cons/cgi/ online.cgi?req=doc;base=LAW; $n=133493$.

Federal Law No. 171-FZ of November 22, 1995 on the State Regulation of the Production and Circulation of Ethyl Alcohol and Alcoholic Drinks and on Restricting the Consumption (Drinking) of Alcohol Products (30.12.2012). Retrieved from http://base.consultant.ru/ cons/cgi/online.cgi?req=doc;base=LAW; $n=139902$.

Federal Law No. 311-FZ of November 27, 2010 on Customs Regulation in the Russian Federation (05.04.2013). Retrieved from http://base.consultant.ru/cons/cgi/online.cgi?req=doc;base $=L A W ; n=144703$.

Federal Law No. 371-FZ of November 22, 2011 on the Federal Budget for 2012 and the Planning Period of 2013 and 2014 (03.12.2012). Retrieved from http://base.consultant.ru/ cons/cgi/online.cgi?req=doc;base=LAW; $=138836$. 
Felipe, J., \& Kumar, U. (2012). The Role of Trade Facilitation in Central Asia. Eastern European Economics, 50(4), 5-20.

Harmonized System Database [in:] World Customs Organisation [online version] http://www .wcoomd.org/en/topics/nomenclature/instrument-and-tools/hs-online.aspx.

Iwasaki, I., \& Suganuma, K., (2013). A Gravity Model of Russian Trade: The Role of Foreign Direct Investment and Socio-Cultural Similarity. Russian Research Centre Working Paper Series, 40. Retrieved from http://www.ier.hit-u.ac.jp/rrc/RRC_WP_No40.pdf.

Karpenko, G., (2013, March 26). Mirovoj jeksport loma 2012: apatija rynka [World export of scrap2012: market apathy]. Retrieved from http://www.ugmk.info/art/mirovoj-jeksport-loma2012-apatija-rynka.html.

Kneller, R., \& Pisu M. (2011). Barriers to Exporting: What are They and Who do They Matter to? The World Economy, 34(6), 893-930.

Order of the Government of the Russian Federation No. 1222-r of September 21, 2004 on the List of Industrial Goods (12.02.2011). Retrieved from http://base.consultant.ru/cons/cgi/online .cgi?req=doc;base=LAW; $=110677$.

Order of the Government of the Russian Federation No. 1493-r of October 14, 2003 on the Concept of the Development of the State Financial (Guaranteed) Support of the Export of Industrial Products in the Russian Federation. Retrieved from http://base.consultant.ru/ cons/cgi/online.cgi?req=doc; base=LAW; $n=127110$.

Order of the Government of the Russian Federation No. 566-r of April 25, 2008. Retrieved from http://base.consultant.ru/cons/cgi/online.cgi?req=doc;base=LAW; $n=76570$.

Order of the Ministry of Industry and Trade of the Russian Federation No. 518 of April 29, 2012 on the Approval of the List of High-Value Added Goods. Retrieved from http://base.consultant .ru/cons/cgi/online.cgi?req=doc;base $=\mathrm{LAW} ; \mathrm{n}=130078$.

Order of the Ministry of Industry and Trade of the Russian Federation No. 1001 of August 25, 2011 on the Approval of the List of High-Value Added Goods. Retrieved from http://base .consultant.ru/cons/cgi/online.cgi?req=doc;base=LAW; $=117942$.

Order of the State Customs Committee of the Russian Federation No. 1219 of December 27, 2000 on Defining Places for the Customs Formalization and Export of Ferrous and Non-Ferrous Metals Scrap and Wastes (9.04.2002). Retrieved from http://base.consultant.ru/cons/ cgi/online.cgi?req=doc; base=LAW; $=13995$.

Order of the State Customs Committee of the Russian Federation No. 184 of March 10, 2000 on Defining Places for the Export of Manchurian Ash and Mongolian Oak. Retrieved from http://base.consultant.ru/cons/cgi/online.cgi?req=doc;base=LAW; $n=26565$.

Passport - statistics database [online version] http://www.portal.euromonitor.com/.

Protocol on the Accession of the Russian Federation to the Marrakesh Agreement of April 15, 1994 on Establishing the World Trade Organization of December 16, 2012. Retrieved from http://base.consultant.ru/cons/cgi/online.cgi?req=doc;base=LAW; $=132721$.

Protocol Resolution of Economic Council of CIS on the Review of Trade Policy of the Russian Federation of September 14, 2012, signed in Ashgabat. Retrieved from http://base.consultant .ru/cons/cgi/online.cgi?req=doc; base=INT; $n=55288$.

Rahman, M. M. (2003). A panel data analysis of Bangladesh's trade: the gravity model approach. In Proceedings of the 5th Annual Conference of the European Trade Study Group (ETSG2003). European Trade Study Group. 
Resolution of the Collegium of the EurAsEc Economic Commission No. 134 of August 16, 2012 on the Legal Acts in the Scope of Non-tariff Regulation (24.04.2013). Retrieved from http://base.consultant.ru/cons/cgi/online.cgi?req=doc;base=LAW; $=145801$.

Resolution of the Commission of the Customs Union No. 168 of January 27, 2010 on the Operation of the Single System of Non-Tariff Regulation in Customs Union of Republic of Belarus, Republic of Kazakhstan and the Russian Federation (25.09.2012). Retrieved from http://base.consultant.ru/cons/cgi/online.cgi?req=doc;base=LAW; $n=135766$.

Suvankulov, F., \& Guc, Y. (2012). Who is trading well in Central Asia? A gravity analysis of exports from the regional powers to the region. Eurasian Journal of Business and Economics, 5(9), 2143.

Tax Code of the Russian Federation of August 5, 2000 (07.05.2013). Retrieved from http://base.consultant.ru/cons/cgi/online.cgi?req=doc;base=LAW; $n=144779$.

The world factbook [in:] The Central Intelligence Agency [online version] https://www.cia .gov/library/publications/the-world-factbook/index.html, (retrieved $28^{\text {th }}$ of May 2013).

Treaty on a Free-Trade Zone of October 18, 2011. Retrieved from http://base.consultant.ru/cons/ cgi/online.cgi?req=doc;base=LAW; $n=121497$.

Vnesheconombank Annual Report-2011 [in:] Vnesheconombank [online version] http://veb.ru/ common/upload/files/veb/reports/annual/VEB_Annual_2011f_r.pdf.

WCO Members [in:] World Customs Organisation [online version] http://www.wcoomd.org/en/ about-us/wco-members/membership.aspx.

Weckström, A., (2013). Gravity Model of Trade and Russian Exports. (Master thesis). Retrieved from http://epub.lib.aalto.fi/fi/ethesis/pdf/13325/hse_ethesis_13325.pdf.

WTO, Members and Observers, Retrieved May 2, 2013, from http://wto.org/english/thewto_e/whatis_e/ tif_e/org6_e.htm.

Zubchenko, E. (2013, May 13). Auditors admitted Russian unavailability to be a WTO member. Novye Izvestia. Retrieved from http://www.newizv.ru/economics/2013-05-13/182124vstuplenie-bez-zavjazki.html. 


\section{Author}

\section{Mikalai Dudko}

Graduated from Belarussian State University (Belarus), where he obtained a specialist (bachelor) degree of customs affairs. Graduated from Cracow University of Economics (Poland), where he obtained a master degree in international business.

\section{Correspondence to:}

Mgr Mikalai Dudko

Independent researcher

dudko.na@gmail.com

Published by Centre for Strategic and International Entrepreneurship - Krakow, Poland 